\title{
HUMAN DEVELOPMENT INDEX AND INEQUALITY ADJUSTED HUMAN DEVELOPMENT INDEX OF SELECTED SOUTH ASIAN COUNTRIES
}

\author{
Dr. Nasheman Bandookwala \\ Dr. Hitesh N. Jagani
}

\begin{abstract}
Enlarging people's choice and enhancing human capabilities" - the well-known definition propounded by Human Development report (HDR) 1990 - led the path for many economists and researchers to turn the lime light on and foray in this direction against predefined notions of economic development and growth. Human development eventually has become a broader and more acceptable concept. Since then, tremendous amount of work has been done in this direction for countries across world. However, such indices for South Asian countries exclusively and comparison therein has remained unattended. The present paper intends to evaluate the human development indices and three key dimension of human development - health, literacy and income. In 2010, HDR, UNDP, proposed the Inequality Adjusted Human Development Index ${ }^{1}$ which tried to gauge the subgroup inequality. The Atkinson Inequality Inde ${ }^{2}$ was used to work out subgroup inequality and to arrive at Inequality Adjusted Human development Index (IHDI). Infact, it was later realised that human development without measuring subgroup inequality would mask reality.

The present paper is predominantly conceived to understand performance of India vis. a vis. other South Asian countries on human development dynamics. Each parameter is carefully analysed to ameliorate understanding of parameters and their impact on human development. The outcome of study is- human development dynamics and human capabilities measurement is redundant and meaningless unless the inequality in each parameter is premeditated which will in turn enhance the understanding.
\end{abstract}

Keywords: Subgroup inequality, development dynamics

\section{Epilogue}

The human development approach - which has become a powerful parameter of the current development discourse - is rooted in a vision of development that sees equality and justice as essential values that must be built into processes of economic growth if it is to be sustainable. As has been proposed by Mahbub-ul Haq, no society can be called developed if one half of its humanity remains voiceless, invisible and undervalued. Moreover, economic growth - regardless of the approach adopted - has been aptly demonstrated to be uneven and unsustainable in the long run if it is sought to be

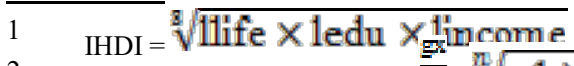

2 Atkinson inequality index $\mathrm{A}=\frac{\underline{u x}}{x 1 \times x 2 \ldots \mathrm{nn}}$
} 
Towards Excellence: An Indexed, Refereed \& Peer Reviewed Journal of Higher Education / Dr. Nasheman Bandookwala \& Dr. Hitesh Jagani/ Page 438-452

realised in a situation where there are significant subgroup inequalities. The human development approach, in terms of social welfare theory, is based on the concept of capabilities that Amartya Sen has so eloquently advocated. Capabilities are defined as a bundle of functioning, which encompass the range of 'doings and beings of people'. Development is defined as the process of enhancing these capabilities for all members of a society. The capabilities approach marks a distinct break from other approaches as it treats human beings as ends in themselves, rather than instruments for other ends. The 1990, HDR introduced an Index that aimed at capturing this capabilities approach However; voluminous work has been done on this by researcher and economist there certainly lies phenomenal gap in evaluating human capabilities and development dynamics in South Asian countries exclusively. The present study is an attempt to bridge the gap, keeping itself confined to selected South Asian countries.

\section{Methodology}

Life Expectancy Index $\left(\mathrm{I}_{\mathrm{x}}\right)=\frac{\text { actualwalua }-25}{85-25}$

Education Index $\left(\mathrm{I}_{\mathrm{y}}\right)$

$=\sqrt{\text { Mean year of schoolin index } X \text { Expected Year of schooling index }}-\frac{0}{0.951-0}$

Where,

Mean year of schooling $=\frac{\text { actualvalua }-0}{100-0}$

Expected year of schooling $=\frac{\text { actualvalua }-0}{100-0}$

PGNI Index $\left(\mathrm{I}_{\mathrm{z}}\right)=\frac{\text { W(ACTUAL VALUE })-W(163)}{W N(108211)-W N(163)}$

$\mathrm{HDI}=\sqrt[\mathbb{s}]{I x \cdot I y \cdot I z}$

$\mathrm{IHDI}=\sqrt[\mathbb{R}]{(1-A l i f e) I x \cdot(1-A e d u) \cdot I y \cdot(1-\text { Aincome }) \cdot I z}$

Where $A_{\text {edu }}$, Alife and $A_{\text {income }}$ are Atkinson inequality index

\section{Human Development and its Component}

It is interesting to analyze the human development and its component of South Asian countries vis-àvis India. The comparison for the year 2010, 2011, 2015 and 2018 is deliberately undertaken as it was in 2010 the IHDI was introduced. In Annexure 1, the component of indices of HDI viz Mean year of schooling, life expectancy, expected year of school and per-capita gross national income are listed. In Annexure 2 the component indices are ranked to examine the performance of India. First rank is 
Towards Excellence: An Indexed, Refereed \& Peer Reviewed Journal of Higher Education / Dr.

Nasheman Bandookwala \& Dr. Hitesh Jagani/ Page 438-452

awarded to the best performing country. In all the four components viz. life expectancy, mean years of schooling, expected years of schooling and per capita gross national income for all the four years, India's performance is dismal. Among 14 South Asian countries considered in the study for all the four components India ranks 11, 11, 10 and 9 respectively for 2010, which further dwindles marginally to 12, 11, 10 and 9 in 2011. whilst in 2015 marginal improvement is recorded in all indicators with rank being $11,8,10$ and 8 receptively and in 2018 EYS rank improved to $8^{\text {th }}$ from $10^{\text {th }}$ with rest remaining almost same to $11,10,8$ and 8 . respectively. The recorded performance of India on these indicators for four years indicates India has long way to travel in human development dynamics. Among countries of South Asia, Singapore is the best performer with first rank in all components for 2015 and 2018. The worst performer for Life expectancy is Pakistan, Nepal for MYS and EYS and Bangladesh and Nepal for National Income. (Annexure 2)

Table :1 Life expectancy Index (Ix), Education Index (Iy)and Percapita gross national Income Index (PGNI) (Iz)

\begin{tabular}{|c|c|c|c|c|c|c|c|c|c|c|c|c|}
\hline \multirow[t]{2}{*}{ Countries } & \multicolumn{3}{|c|}{2010} & \multicolumn{3}{|c|}{2011} & \multicolumn{3}{|c|}{2015} & \multicolumn{3}{|c|}{2018} \\
\hline & $\mathrm{I}_{\mathrm{x}}$ & $\mathrm{I}_{\mathrm{y}}$ & $\mathrm{I}_{\mathrm{z}}$ & $\mathrm{I}_{\mathrm{x}}$ & $\mathrm{I}_{\mathrm{y}}$ & $\mathrm{I}_{\mathrm{z}}$ & $\mathrm{I}_{\mathrm{x}}$ & $\mathrm{I}_{\mathrm{y}}$ & $\mathrm{I}_{\mathrm{z}}$ & $\mathrm{I}_{\mathrm{x}}$ & $\mathrm{I}_{\mathrm{y}}$ & $\mathrm{I}_{\mathrm{z}}$ \\
\hline Bangladesh & 0.59 & 0.53 & 0.33 & 0.77 & 0.16 & 0.34 & 0.82 & 0.46 & 0.46 & 0.83 & 0.53 & 0.49 \\
\hline Bhutan & 0.74 & NA & 0.54 & 0.75 & 0.18 & 0.54 & 0.79 & 0.47 & 0.54 & 0.81 & 0.39 & 0.61 \\
\hline India & 0.70 & 0.43 & 0.46 & 0.72 & 0.17 & 0.47 & 0.76 & 0.55 & 0.55 & 0.78 & 0.57 & 0.57 \\
\hline Indonesia & 0.81 & 0.54 & 0.49 & 0.78 & 0.20 & 0.48 & 0.78 & 0.64 & 0.63 & 0.84 & 0.73 & 0.55 \\
\hline Malaysia & 0.87 & 0.69 & 0.68 & 0.86 & 0.21 & 0.68 & 0.87 & 0.73 & 0.75 & 0.89 & 0.75 & 0.79 \\
\hline Maldives & 0.83 & 0.49 & 0.54 & 0.90 & 0.21 & 0.54 & 0.90 & 0.57 & 0.64 & 0.93 & 0.58 & 0.67 \\
\hline Myanmar & 0.68 & 0.39 & 0.35 & 0.72 & 0.16 & 0.35 & 0.73 & 0.42 & 0.53 & 0.74 & 0.46 & 0.55 \\
\hline Nepal & 0.75 & 0.34 & 0.31 & 0.77 & 0.17 & 0.30 & 0.79 & 0.45 & 0.41 & 0.73 & 0.55 & 0.45 \\
\hline Pakistan & 0.54 & 0.47 & 0.46 & 0.72 & 0.14 & 0.42 & 0.73 & 0.41 & 0.53 & 0.75 & 0.42 & 0.53 \\
\hline Philippines & 0.83 & 0.64 & 0.49 & 0.77 & 0.19 & 0.47 & 0.76 & 0.67 & 0.61 & 0.81 & 0.70 & 0.63 \\
\hline Singapore & 0.96 & 0.72 & 0.88 & 0.97 & 0.24 & 0.89 & 1.00 & 0.85 & 0.95 & 1.00 & 0.87 & 0.96 \\
\hline Srilanka & 0.86 & 0.63 & 0.52 & 0.87 & 0.21 & 0.53 & 0.87 & 0.79 & 0.65 & 0.90 & 0.79 & 0.66 \\
\hline Thailand & 0.78 & 0.60 & 0.60 & 0.86 & 0.21 & 0.59 & 0.86 & 0.66 & 0.69 & 0.87 & 0.68 & 0.71 \\
\hline Vietnam & 0.87 & 0.48 & 0.45 & 0.87 & 0.19 & 0.44 & 0.88 & 0.64 & 0.54 & 0.88 & 0.65 & 0.56 \\
\hline
\end{tabular}



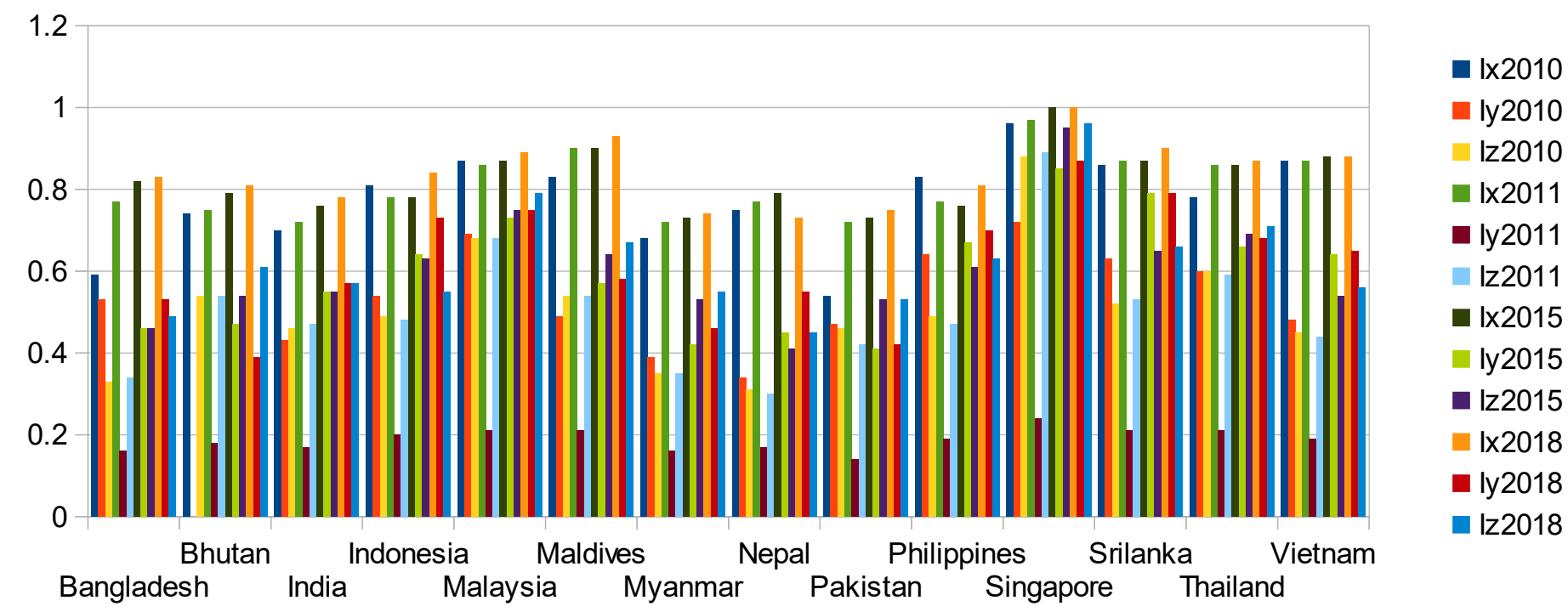

As mentioned earlier the concern here is to assess and meticulously analyze the Inequality Adjusted Human development index and its component as propounded in the HDR 2010. Nonetheless Ix, Iy and Iz as well needs to be thoroughly analyzed to get wholesome insight of inequality prevailing each component. The Table 1 above exhibits the HDI components viz Ix, Iy and Iz for the year 2010, 2011, 2015 and 2018 to have cross sectional understanding. Furthermore, the attempt is done in the study to ameliorate the understanding of loss in each index due to inequality. The percentage loss in human development due inequality for each South Asian country has been depicted in Table 2 while the loss for each individual component i.e. Life expectancy index, Education Index and income index is calculated in Table 3. Maldives exhibits the least loss in human development out of the fourteen countries when inequality adjusted human development is calculated for the 2010. This indicates that less inequality prevails in Maldives and all three parameters of human development viz. health, education and income is given due significance by the concern authorities. For 2011 Thailand exhibits least loss in human development with inequality being the least. In 2015 Srilanka is the country with least loss while in 2018 when Singapore data is recorded (data for 2010,2011 and 2015 is not recorded) the least loss in human development obviously is in Singapore. Analyzing trend in inequality for India 
Towards Excellence: An Indexed, Refereed \& Peer Reviewed Journal of Higher Education / Dr. Nasheman Bandookwala \& Dr. Hitesh Jagani/ Page 438-452

the country is on $8^{\text {th }}$ rank in 2010 , on $7^{\text {th }}$ rank for both 2011 and 2015 and on $4^{\text {th }}$ rank in 2018 indicating high level of inequality resulting into substantial loss in human development ${ }^{3}$

3 Rank for inequality in human development is allotted in descending order meaning country with highest inequality is allotted first rank 
Towards Excellence: An Indexed, Refereed \& Peer Reviewed Journal of Higher Education / Dr. Nasheman Bandookwala \& Dr. Hitesh Jagani/ Page 438-452

Table :2 Inequality Adjusted Human Development Index and its components

\begin{tabular}{|c|c|c|c|c|c|c|c|c|c|c|c|c|c|c|c|c|c|c|c|c|}
\hline & \multicolumn{5}{|c|}{2010} & \multicolumn{5}{|c|}{2011} & \multicolumn{5}{|c|}{2015} & \multicolumn{5}{|c|}{2018} \\
\hline Countries & IHDI & Iix & Iiy & Iiz & $\begin{array}{c}\% \\
\text { Loss }\end{array}$ & IHDI & Iix & Iiy & Iiz & $\begin{array}{c}\% \\
\text { Loss }\end{array}$ & IHDI & Iix & Iiy & Iiz & \% Loss & IHDI & Iix & Iiy & Iiz & $\begin{array}{c}\% \\
\text { Loss }\end{array}$ \\
\hline Bangladesh & 0.331 & 0.555 & 0.219 & 0.2999 & 29.4 & 0.363 & 0.593 & 0.252 & 0.321 & 27.4 & 0.412 & 0.639 & 0.287 & 0.380 & 28.9 & 0.465 & 0.666 & 0.320 & 0.472 & 24.5 \\
\hline Bhutan & NA & NA & NA & NA & NA & NA & 0.565 & 0.185 & NA & NA & 0.428 & 0.608 & 0.280 & 0.517 & 29.4 & 0.450 & 0.656 & 0.257 & 0.539 & 27.1 \\
\hline India & 0.365 & 0.483 & 0.255 & 0.347 & 29.8 & 0.392 & 0.522 & 0.267 & 0.433 & 28.3 & 0.454 & 0.565 & 0.324 & 0.512 & 27.2 & 0.477 & 0.520 & 0.437 & 0.321 & 26.3 \\
\hline Indonesia & 0.494 & 0.678 & 0.424 & 0.418 & 17.7 & 0.504 & 0.648 & 0.465 & 0.426 & 18.3 & 0.563 & 0.630 & 0.492 & 0.576 & 18.2 & 0.584 & 0.682 & 0.511 & 0.570 & 17.4 \\
\hline Malaysia & $\mathrm{NA}$ & 0.797 & NA & $\mathrm{NA}$ & NA & NA & 0.798 & NA & NA & NA & NA & NA & NA & NA & NA & NA & NA & NA & NA & NA \\
\hline Maldives & 0.508 & 0.7 & 0.433 & 0.404 & 15.6 & 0.495 & 0.832 & 0.334 & 0.436 & 25.2 & 0.529 & 0.814 & 0.337 & 0.539 & 24.6 & 0.430 & 0.641 & 0.296 & 0.419 & 25.8 \\
\hline Myanmar & $\mathrm{NA}$ & NA & NA & $\mathrm{NA}$ & $\mathrm{NA}$ & NA & 0.533 & $\mathrm{NA}$ & NA & NA & NA & NA & NA & NA & NA & NA & NA & NA & $\mathrm{NA}$ & NA \\
\hline Nepal & 0.292 & 0.569 & 0.193 & 0.226 & 31.9 & 0.301 & 0.62 & 0.201 & 0.22 & 34.3 & 0.407 & 0.618 & 0.267 & 0.410 & 27 & 0.430 & 0.641 & 0.296 & 0.419 & 25.8 \\
\hline Pakistan & 0.336 & 0.501 & 0.196 & 0.385 & 31.5 & 0.346 & 0.485 & 0.207 & 0.413 & 31.4 & 0.380 & 0.479 & 0.220 & 0.523 & 30.9 & 0.380 & 0.508 & 0.230 & 0.494 & 31.1 \\
\hline Philippines & 0.518 & 0.705 & 0.554 & 0.355 & 18.9 & 0.516 & 0.652 & 0.592 & 0.356 & 19.9 & 0.556 & 0.623 & 0.563 & 0.490 & 18.4 & 0.582 & 0.666 & 0.599 & 0.495 & 18.2 \\
\hline Singapore & $\mathrm{NA}$ & 0.925 & NA & $\mathrm{NA}$ & $\mathrm{NA}$ & NA & 0.936 & NA & NA & NA & NA & NA & NA & NA & $\mathrm{NA}$ & 0.810 & 0.952 & 0.745 & 0.750 & 13.3 \\
\hline Srilanka & 0.546 & 0.756 & 0.519 & 0.414 & 17.1 & 0.579 & 0.785 & 0.558 & 0.442 & 16.2 & 0.678 & 0.778 & 0.656 & 0.610 & 11.6 & 0.686 & 0.813 & 0.7 .00 & 0.567 & 17.7 \\
\hline Thailand & 0.516 & 0.706 & 0.491 & 0.396 & 21.2 & 0.537 & 768 & 0.459 & 0.411 & 21.3 & 0.586 & 0.753 & 0.538 & 0.496 & 20.5 & 0.635 & 0.807 & 0.543 & 0.585 & 16.9 \\
\hline Vietnam & 0.478 & 0.75 & 0.398 & 0.367 & 16.4 & 0.51 & 0.754 & 0.417 & 0.423 & 14 & 0.562 & 0.738 & 0.508 & 0.472 & 17.8 & 0.580 & 0.741 & 0.515 & 0.511 & 16.3 \\
\hline
\end{tabular}

Source: HDR,UNDP 2010, 2011,2015 and 2019

Note IHDI = Inequality Adjusted Human Development Index.

Iix = Inequality Adjusted Life Expectancy index.

Iiy $=$ Inequality Adjusted Education Index.

$\mathrm{Iiz}=$ Inequality Adjusted Income Index. 
Towards Excellence: An Indexed, Refereed \& Peer Reviewed Journal of Higher Education / Dr. Nasheman Bandookwala \& Dr. Hitesh Jagani/ Page 438-452

\begin{tabular}{|c|c|c|c|c|c|c|c|c|c|c|c|c|c|c|c|}
\hline \multirow[b]{2}{*}{ Countries } & \multicolumn{3}{|c|}{2010} & \multicolumn{3}{|c|}{2011} & \multicolumn{3}{|c|}{2015} & \multicolumn{3}{|c|}{2018} & \multirow{2}{*}{$\begin{array}{l}\text { CARG in } \\
\text { inequality } \\
\text { in Life } \\
\text { expectanc } \\
y \text { index }\end{array}$} & \multirow{2}{*}{$\begin{array}{c}\text { CARG in } \\
\text { inequality } \\
\text { in } \\
\text { education } \\
\text { index }\end{array}$} & \multirow{2}{*}{$\begin{array}{c}\text { CARG in } \\
\text { inequality } \\
\text { in Income } \\
\text { index }\end{array}$} \\
\hline & $\begin{array}{l}\text { Loss Life } \\
\text { Expectancy } \\
\text { index }\end{array}$ & $\begin{array}{l}\text { Loss } \\
\text { education } \\
\text { Index }\end{array}$ & $\begin{array}{l}\text { Loss } \\
\text { Income } \\
\text { Index }\end{array}$ & $\begin{array}{l}\text { Loss Life } \\
\text { Expectancy } \\
\text { index }\end{array}$ & $\begin{array}{l}\text { Loss } \\
\text { education } \\
\text { Index }\end{array}$ & $\begin{array}{l}\text { Loss } \\
\text { Income } \\
\text { Index }\end{array}$ & $\begin{array}{l}\text { Loss Life } \\
\text { Expectancy } \\
\text { index }\end{array}$ & $\begin{array}{l}\text { Loss } \\
\text { education } \\
\text { Index }\end{array}$ & $\begin{array}{l}\text { Loss } \\
\text { Income } \\
\text { Index }\end{array}$ & $\begin{array}{l}\text { Loss Life } \\
\text { Expectancy } \\
\text { index }\end{array}$ & $\begin{array}{l}\text { Loss } \\
\text { education } \\
\text { Index }\end{array}$ & $\begin{array}{l}\text { Loss } \\
\text { Income } \\
\text { Index }\end{array}$ & & & \\
\hline Bangladesh & 5.45 & 58.60 & 8.84 & 23.09 & 39.28 & 17.69 & 22.07 & 37.61 & 17.39 & 19.76 & 39.62 & 3.67 & 0.17 & 0.05 & 0.10 \\
\hline Bhutan & NA & NA & NA & 24.06 & 44.78 & NA & 23.04 & 40.43 & 4.26 & 19.01 & 34.10 & 11.64 & 0.00 & 0.00 & 0.00 \\
\hline India & 31.29 & 40.56 & 25.38 & 27.09 & 40.40 & 14.76 & 25.66 & 41.09 & 6.91 & 33.33 & 23.33 & 43.68 & 0.01 & 0.07 & -0.07 \\
\hline Indonesia & 16.81 & 21.92 & 14.87 & 16.82 & 20.24 & 17.60 & 19.23 & 23.13 & 8.57 & 18.81 & 30.00 & 7.27 & 0.01 & -0.04 & 0.09 \\
\hline Malaysia & 7.97 & NA & NA & 6.67 & NA & NA & NA & NA & NA & NA & NA & NA & 0.00 & 0.00 & 0.00 \\
\hline Maldives & 15.46 & 11.09 & 25.05 & 7.14 & 40.88 & 23.24 & 9.56 & 40.88 & 15.78 & 31.08 & 48.97 & 37.46 & 0.09 & -0.20 & -0.05 \\
\hline Myanmar & NA & NA & NA & 25.25 & NA & NA & NA & NA & NA & NA & NA & 0.00 & 0.00 & 0.00 & 0.00 \\
\hline Nepal & 24.34 & 42.90 & 26.38 & 19.48 & 43.06 & 37.32 & 21.77 & 40.67 & 0.00 & 12.19 & 46.18 & 6.89 & -0.08 & -0.01 & 0.15 \\
\hline Pakistan & 6.53 & 58.47 & 16.49 & 32.26 & 46.51 & 10.99 & 34.38 & 46.34 & 1.32 & 32.27 & 45.24 & 6.79 & 0.22 & 0.03 & 0.10 \\
\hline Philippines & 14.86 & NA & 27.99 & 15.10 & 13.58 & 29.92 & 18.03 & 15.97 & 19.67 & 17.78 & 14.43 & 21.43 & 0.02 & 0.00 & 0.03 \\
\hline Singapore & 3.65 & NA & NA & 2.90 & NA & NA & NA & NA & NA & 4.80 & 14.37 & 21.88 & 0.03 & 0.00 & 0.00 \\
\hline Srilanka & 12.20 & 18.01 & 20.84 & 9.35 & 17.94 & 20.79 & 10.57 & 16.96 & 6.15 & 9.67 & 11.39 & 14.09 & -0.03 & 0.06 & 0.05 \\
\hline Thailand & 9.49 & 18.44 & 33.89 & 10 & 23.50 & 33.92 & 12.44 & 18.48 & 28.12 & 7.24 & 20.15 & 17.61 & -0.03 & -0.01 & 0.08 \\
\hline Vietnam & 13.69 & 17.43 & 18.08 & 13.43 & 17.26 & 11.32 & 16.14 & 20.63 & 12.59 & 15.80 & 20.77 & 8.75 & 0.02 & -0.02 & 0.09 \\
\hline
\end{tabular}

Source: Calculated by authors 
Towards Excellence: An Indexed, Refereed \& Peer Reviewed Journal of Higher Education / Dr.

Nasheman Bandookwala \& Dr. Hitesh Jagani/ Page 438-452

Countries of South Asia have exhibited increase in loss for different indices due to subgroup inequality. For Life expectancy Nepal, Srilanka and Thailand records negative CARG indicating reduction inequality however complete elimination is yet not achieved. For education index, Indonesia, Nepal, Maldives and Vietnam records negative CARG indicating reduction in inequality compared to 2010. For Income index India records negative CARG and indicates country has reduced sub group inequality in income, other than India Maldives has reduce subgroup income inequality. Unless, countries reduce these sub group inequalities the human development is partial and prejudiced. 
Towards Excellence: An Indexed, Refereed \& Peer Reviewed Journal of Higher Education / Dr. Nasheman Bandookwala \& Dr. Hitesh Jagani/ Page 438-452

Table: 4 Human development parameters and descriptive statistics

\begin{tabular}{|c|c|c|c|c|c|c|c|c|c|c|c|c|c|c|c|c|c|c|c|c|}
\hline Item & \multicolumn{5}{|c|}{2010} & \multicolumn{5}{|c|}{2011} & \multicolumn{5}{|c|}{2015} & \multicolumn{5}{|c|}{2018} \\
\hline & Mean & $\begin{array}{l}\text { Standard } \\
\text { deviation }\end{array}$ & $\begin{array}{c}\text { Minimum } \\
\text { value }\end{array}$ & $\begin{array}{c}\text { Maximum } \\
\text { value }\end{array}$ & $\begin{array}{c}\text { Co- } \\
\text { eficient of } \\
\text { Variation }\end{array}$ & Mean & $\begin{array}{l}\text { Standard } \\
\text { deviation }\end{array}$ & $\begin{array}{c}\text { Minimum } \\
\text { value }\end{array}$ & $\begin{array}{c}\text { Maximum } \\
\text { value }\end{array}$ & $\begin{array}{c}\text { Co- } \\
\text { eficient of } \\
\text { Variation }\end{array}$ & Mean & $\begin{array}{l}\begin{array}{c}\text { Standard } \\
\text { deviation }\end{array} \\
\end{array}$ & $\begin{array}{c}\text { Minimum } \\
\text { value }\end{array}$ & $\begin{array}{c}\text { Maximum } \\
\text { value }\end{array}$ & $\begin{array}{c}\text { Co- } \\
\text { eficient of } \\
\text { Variation }\end{array}$ & Mean & Standard deviation & $\begin{array}{c}\text { Minimum } \\
\text { value }\end{array}$ & $\begin{array}{c}\begin{array}{c}\text { Maximum } \\
\text { value }\end{array} \\
\text { vall }\end{array}$ & $\begin{array}{c}\text { Co- } \\
\text { eficient of } \\
\text { Variation }\end{array}$ \\
\hline HDI & 0.59 & 0.12 & 0.43 & 0.85 & 0.35 & 0.61 & 0.12 & 0.46 & 0.87 & 0.34 & 0.68 & 0.11 & 0.55 & 0.93 & 0.33 & 0.69 & 0.11 & 0.56 & 0.94 & 0.33 \\
\hline IHDI & 0.44 & 0.10 & 0.55 & 0.29 & 0.31 & 0.45 & 0.09 & 0.30 & 0.58 & 0.31 & 0.51 & 0.09 & 0.38 & 0.68 & 0.31 & 0.54 & 0.13 & 0.38 & 0.81 & 0.36 \\
\hline LE & $\begin{array}{r}68.7 \\
5\end{array}$ & 7.33 & 53.90 & 80.70 & 2.71 & $\begin{array}{r}71.0 \\
9\end{array}$ & 4.93 & 65.20 & 81.10 & 2.22 & $\begin{array}{r}72.1 \\
9\end{array}$ & 4.80 & 66.10 & 83.20 & 2.19 & $\begin{array}{r}73.0 \\
6\end{array}$ & 4.88 & 66.30 & 83.50 & 2.21 \\
\hline $\begin{array}{l}\text { MYS } \\
\end{array}$ & 6.33 & 2.02 & 3.20 & 9.50 & 1.42 & 5.91 & 2.23 & 2.30 & 9.50 & 1.49 & 7.26 & 2.50 & 4.10 & 11.60 & 1.58 & 7.71 & 2.55 & 3.10 & 11.50 & 1.60 \\
\hline EYS & $\begin{array}{r}11.2 \\
7\end{array}$ & 1.79 & 8.80 & 14.40 & 1.34 & $\begin{array}{r}11.0 \\
1\end{array}$ & 2.16 & 6.90 & 14.40 & 1.47 & $\begin{array}{r}12.1 \\
3\end{array}$ & 1.92 & 8.10 & 15.40 & 1.39 & $\begin{array}{r}12.4 \\
3\end{array}$ & 1.91 & 8.50 & 16.30 & 1.38 \\
\hline PGNI & $\begin{array}{l}7,74 \\
6.64\end{array}$ & $\begin{array}{r}12,2 \\
82.6 \\
2\end{array}$ & $\begin{array}{r}1,201 \\
.00\end{array}$ & $\begin{array}{r}48,89 \\
3.00\end{array}$ & $\begin{array}{r}110 . \\
83\end{array}$ & $\begin{array}{l}7,83 \\
5.79\end{array}$ & $\begin{array}{r}13,2 \\
69.4 \\
3\end{array}$ & $\begin{array}{r}1,160 \\
.00\end{array}$ & $\begin{array}{r}52,56 \\
9.00\end{array}$ & $\begin{array}{r}115 . \\
19\end{array}$ & $\begin{array}{r}132 \\
77.6 \\
4\end{array}$ & $\begin{array}{r}1935 \\
2.01\end{array}$ & 2337 & $\begin{array}{r}7816 \\
2\end{array}$ & $\begin{array}{r}139 . \\
11\end{array}$ & $\begin{array}{r}14,7 \\
46.7 \\
9\end{array}$ & $20,831.71$ & $\begin{array}{r}3,052 \\
.00\end{array}$ & $\begin{array}{r}83,79 \\
3.00\end{array}$ & $\begin{array}{r}144.3 \\
3\end{array}$ \\
\hline
\end{tabular}

Source : Calculated by authors 
Towards Excellence: An Indexed, Refereed \& Peer Reviewed Journal of Higher Education / Dr. Nasheman Bandookwala \& Dr. Hitesh Jagani/ Page 438-452

The average increase in HDI over eight years (2010 to 2018) is 14.5\% while increase in IHDI is $18.8 \%$ The health parameters of countries of South Asia have recorded an improvement with mean increase in life expectancy of $6.2 \%$. The education indicators have shown average increase of $10.2 \%$ with expected years of educations increasing from 11.27 to 12.24 among countries. A phenomenal growth in per capita gross national income is recorded in eight years with mean of the parameter rising to $90.3 \%$.

The standard deviation of HDI and life expectancy has become negative during these eight years while for per capita national income has increased to 0.69 indicating high incidence of variation among countries in income indicators with countries like Singapore having very high per-capita income and others like Bangladesh and Nepal with low PGNI. It is undesirable to have such wide income inequality. Minimum value for Mean years of schooling (MYS) has reduced. In Bhutan MYS for 2018 is recorded to be 3.1 years which is lowest among countries of South Asia. For expected years of schooling (EYS) the increase has been recorded at Singapore from 14.7 to 16.3. India records EYS of 12.3 in 2018 against 10.3 in 2010.

\section{Epilogue}

The human development dynamics across the South Asian countries have demonstrate high flavor of inequality across sub group and hence when inequality across sub group is measured the outcome of loss was significant and is a matter of concern. The mean and standard deviation across countries have exhibited high incidence of variation with a country having very high PGNI of $83,000 \$$ to low of $4,000 \$$. Apart from economic parameters social parameters have as well exhibited high variance and hence substantiated the inequality among the countries. The study clearly emphasis that human development dynamics and human capabilities measurement is redundant and meaningless unless the inequality in each parameter is premeditated which will in turn ameliorate the of understanding of human capital as a foremost essential for countries to attend with priority. The countries covered in the study is evaluated on each parameters and its imperative inequality in each indicators needs to reduced and eventually eliminated for better human development and happier tomorrow.

\section{Notes}

1. The countries are selected on basis of its economic relation with India

2. The selection of the year viz 2010 and 2018 is because in 2010 HDR started reporting IHDI and various other inequality parameters like Gender inequality and multidimensional poverty index although the rest two index is not in the scope of the study. 
Towards Excellence: An Indexed, Refereed \& Peer Reviewed Journal of Higher Education / Dr. Nasheman Bandookwala \& Dr. Hitesh Jagani/ Page 438-452

3. For the year 2019 and 2020 the data is not yet published in HDR and hence is not covered.

4. Please refer keynotes of HDR 2010 for further clarification regarding the method of calculation of HDI and IHDI

5. HDR was first published in 1990 and HDI was calculated as an average of health, education and income index later the calculation was altered to geometric mean in HDR 2010.

6. The HDR 1990, calculated HDI for 130 countries with India being listed as Low human development country and HDI of 0.439 . 
Towards Excellence: An Indexed, Refereed \& Peer Reviewed Journal of Higher Education / Dr. Nasheman Bandookwala \& Dr. Hitesh Jagani/ Page 438-452

\section{References:}

(1) Darshini,(2002) Health for all in Gujarat: Is it achievable, Dynamics of Development in Gujarat, Centre for Development Alternatives Ahmedabad

(2) Nethi and Fidzani,( 2003) "Human Capabilities Approach to the development of developing countries”,pp3-11, Ruddar \& Dutta, “Human Development and Economic Development”. Deep and Deep Publication Pvt Ltd, Mehta, "Human Development and Economic Growth: The experience of India 1980-1996 pp 12-25, Ruddar \& Dutta,"Human Development and Economic Development". Deep and Deep Publication Pvt Ltd,

(3) Sengupta,(2003) "Economic Growth and its impact on Human Development on the Indian Economy". pp 167-188, Ruddar \& Dutta, "Human Development and Economic Development". Deep and Deep Publication Pvt Ltd,

(4) Guha,(2003)“Human Development in India-A study of inter-states disparity”. Pp 211-229, Ruddar \& Dutta,"Human Development and Economic Development". Deep and Deep Publication Pvt Ltd,

(5) Gulam (2009), "Human Development: Measurement and Inter State Inequality”. Anvesak Vol 39. 2 July- December 2009

(6) Mandal,920030 "Interstate Comparison of Human Developmenr in India An alternative measure”,pp 197-209, Ruddar \& Dutta,“Human Development and Economic Development”. Deep and Deep Publication Pvt Ltd,

(7) Hirway and Mahadevia(1996.), "Critique of Gender Development Index towards an alternative" Economic and Political Weekly .October 26,

(8) Hirway and Mahadevia, "Human Development and Gender Development in Gujarat" pp 151194, .Editor R. Swaminathan, "Gujarat Perspective of the future”, Academic Foundation New Delhi

(9) Stanton, "The Human Development Index: A History "working paper Political Economy Research Institute, University of Massachusetts Amherst.

(10) Subharao, "FDI and Human Capital Development” Working Paper IIMA, India.

(11) Suryanarayan, Agrawal, Prabhu “ Inequality adjusted Human Development Index for India's states" UNDP

(12) Human Development in South Asia 2014 - Urbanization: Challenges and Opportunities 
Towards Excellence: An Indexed, Refereed \& Peer Reviewed Journal of Higher Education / Dr.

Nasheman Bandookwala \& Dr. Hitesh Jagani/ Page 438-452

\begin{tabular}{|c|c|c|c|c|c|c|c|c|c|c|c|c|c|c|c|c|c|c|c|c|c|c|c|c|}
\hline & \multicolumn{6}{|c|}{2010} & \multicolumn{6}{|c|}{2011} & \multicolumn{6}{|c|}{2015} & \multicolumn{6}{|c|}{2018} \\
\hline Countries & HDI & LE & MYS & EYS & $\begin{array}{l}\text { PGNI } \\
\text { (PPP\$) }\end{array}$ & $\begin{array}{l}\text { HDI } \\
\text { Rank }\end{array}$ & HDI & LE & MYS & EYS & $\begin{array}{l}\text { PGNI } \\
\text { (PPP\$) }\end{array}$ & $\begin{array}{l}\text { HDI } \\
\text { Rank }\end{array}$ & HDI & LE & MYS & EYS & $\begin{array}{l}\text { PGNI } \\
\text { (PPP\$) }\end{array}$ & $\begin{array}{l}\text { HDI } \\
\text { Rank }\end{array}$ & HDI & LE & MYS & EYS & $\begin{array}{l}\text { PGNI } \\
\text { (PPP\$) }\end{array}$ & $\begin{array}{l}\text { HDI } \\
\text { Rank }\end{array}$ \\
\hline Bangladesh & 0.47 & $\begin{array}{r}57 . \\
1\end{array}$ & 7.1 & 9.7 & 1385 & 129 & 0.5 & 68.9 & 4.8 & 8.1 & 1529 & 146 & 0.58 & 72 & 5.2 & 10.2 & 3341 & 139 & 0.61 & 72.3 & 6.1 & 11.2 & 4057 & 135 \\
\hline Bhutan & - & $\begin{array}{r}66 . \\
8\end{array}$ & - & 11.3 & 5607 & & 0.52 & 67.2 & 2.3 & 11 & 5293 & 141 & 0.61 & 69.9 & 4.4 & 12.5 & 5371 & 132 & 0.61 & 71.5 & 3.1 & 12.1 & 8609 & 134 \\
\hline India & 0.52 & $\begin{array}{r}64 . \\
4\end{array}$ & 4.4 & 10.3 & 3337 & 119 & 0.55 & 65.4 & 4.4 & 10.3 & 3468 & 134 & 0.62 & 68.3 & 6.3 & 11.7 & 5663 & 131 & 0.65 & 69.4 & 6.5 & 12.3 & 6829 & 129 \\
\hline Indonesia & 0.6 & $\begin{array}{r}71 . \\
5\end{array}$ & 5.7 & 12.7 & 3957 & 108 & 0.62 & 69.4 & 5.8 & 13.2 & 3716 & 124 & 0.69 & 69.1 & 7.9 & 12.9 & 10053 & 113 & 0.71 & 73.2 & 10.6 & 12.5 & 5885 & 111 \\
\hline Malaysia & 0.74 & $\begin{array}{r}74 . \\
7\end{array}$ & 9.5 & 12.5 & 13927 & 57 & 0.76 & 74.2 & 9.5 & 12.6 & 13685 & 61 & 0.79 & 74.9 & 10.1 & 13.1 & 21565 & 59 & 0.8 & 76 & 10.2 & 13.5 & 27227 & 61 \\
\hline Maldives & 0.6 & $\begin{array}{r}72 . \\
3\end{array}$ & 4.7 & 12.4 & 5408 & 107 & 0.66 & 76.8 & 5.8 & 12.4 & 5276 & 109 & 0.7 & 77 & 6.2 & 12.7 & 10383 & 105 & 0.72 & 78.6 & 6.8 & 12.1 & 12549 & 104 \\
\hline Myanmar & 0.46 & $\begin{array}{r}62 . \\
7\end{array}$ & 4 & 9.2 & 1596 & 132 & 0.48 & 65.2 & 4 & 9.2 & 1535 & 149 & 0.56 & 66.1 & 4.7 & 9.1 & 4943 & 145 & 0.58 & 66.9 & 5 & 10.3 & 5764 & 145 \\
\hline Nepal & 0.43 & $\begin{array}{r}67 . \\
5\end{array}$ & 3.2 & 8.8 & 1201 & 138 & 0.46 & 68.8 & 3.2 & 8.8 & 1160 & 157 & 0.56 & 70 & 4.1 & 12.2 & 2337 & 144 & 0.58 & 66.3 & 6.6 & 11.1 & 3052 & 147 \\
\hline Pakistan & 0.49 & $\begin{array}{r}53 . \\
9\end{array}$ & 5.9 & 9.3 & 3258 & 125 & 0.5 & 65.4 & 4.9 & 6.9 & 2550 & 145 & 0.55 & 66.4 & 5.1 & 8.1 & 5031 & 147 & 0.56 & 67.1 & 5.2 & 8.5 & 5190 & 152 \\
\hline Philippines & 0.64 & $\begin{array}{r}72 . \\
3\end{array}$ & 8.7 & 11,5 & 4002 & 97 & 0.64 & 68.7 & 8.9 & 11.9 & 3478 & 112 & 0.68 & 68.3 & 9.3 & 11.7 & 8395 & 116 & 0.71 & 71.1 & 9.4 & 12.7 & 9540 & 106 \\
\hline Singapore & 0.85 & $\begin{array}{r}80 . \\
7\end{array}$ & 8.8 & 14.4 & 48893 & 27 & 0.87 & 81.1 & 8.8 & 14.4 & 52569 & 26 & 0.93 & 83.2 & 11.6 & 15.4 & 78162 & 5 & 0.94 & 83.5 & 11.5 & 16.3 & 83793 & 9 \\
\hline Srilanka & 0.66 & $\begin{array}{r}74 . \\
4\end{array}$ & 8.2 & 12 & 4886 & 91 & 0.69 & 74.9 & 8.2 & 12.7 & 4943 & 97 & 0.77 & 75 & 10.9 & 14 & 10789 & 73 & 0.78 & 76.8 & 11.1 & 14 & 11611 & 71 \\
\hline Thailand & 0.68 & $\begin{array}{r}69 . \\
3\end{array}$ & 6.6 & 13.5 & 8001 & 92 & 0.68 & 74.1 & 6.6 & 12.3 & 7694 & 103 & 0.74 & 74.6 & 7.9 & 13.6 & 14519 & 37 & 0.77 & 74.9 & 7.7 & 14.7 & 16129 & 77 \\
\hline & 0.57 & $\begin{array}{r}74 . \\
9\end{array}$ & & 10.4 & 2995 & 113 & 0.59 & 75.2 & 5.5 & 10.4 & 2805 & 128 & 0.68 & 75.9 & 8 & 12.6 & 5335 & 115 & 0.69 & 75.3 & 8.2 & 12.7 & 6220 & 118 \\
\hline
\end{tabular}


Towards Excellence: An Indexed, Refereed \& Peer Reviewed Journal of Higher Education / Dr.

Nasheman Bandookwala \& Dr. Hitesh Jagani/ Page 438-452

Annexure 1

\begin{tabular}{|c|c|c|c|c|c|c|c|c|c|c|c|c|c|c|c|c|}
\hline \multirow[t]{2}{*}{ Countries } & \multicolumn{4}{|c|}{2010} & \multicolumn{4}{|c|}{2011} & \multicolumn{4}{|c|}{2015} & \multicolumn{4}{|c|}{2018} \\
\hline & $\begin{array}{l}\mathbf{L} \\
\mathbf{E} \\
\mathbf{R} \\
\mathbf{a} \\
\mathbf{n} \\
\mathbf{k}\end{array}$ & $\begin{array}{l}\text { M } \\
\text { YS } \\
\text { Ra } \\
\text { nk }\end{array}$ & $\begin{array}{l}\text { EY } \\
\text { S } \\
\text { Ra } \\
\text { nk }\end{array}$ & $\begin{array}{l}\text { PG } \\
\text { NI } \\
\text { Ran } \\
k\end{array}$ & $\begin{array}{l}\text { LE } \\
\text { Ra } \\
\text { nk }\end{array}$ & $\begin{array}{l}\text { M } \\
\text { YS } \\
\text { Ra } \\
\text { nk }\end{array}$ & $\begin{array}{l}\text { EY } \\
\text { S } \\
\text { Ra } \\
\text { nk }\end{array}$ & $\begin{array}{l}\text { PG } \\
\text { NI } \\
\text { Ran } \\
k\end{array}$ & $\begin{array}{l}\text { LE } \\
\text { Ra } \\
\text { nk }\end{array}$ & $\begin{array}{l}\text { MY } \\
\text { S } \\
\text { Ra } \\
\text { nk }\end{array}$ & $\begin{array}{l}\text { EY } \\
\text { S } \\
\text { Ra } \\
\text { nk }\end{array}$ & $\begin{array}{l}\text { PG } \\
\text { NI } \\
\text { Ran } \\
k\end{array}$ & $\begin{array}{l}\text { LE } \\
\text { Ran } \\
\mathbf{k}\end{array}$ & $\begin{array}{l}\text { MYS } \\
\text { Ran } \\
\mathbf{k}\end{array}$ & $\begin{array}{l}\text { EYS } \\
\text { Ran } \\
\mathbf{k}\end{array}$ & $\begin{array}{l}\text { PGN } \\
\text { I } \\
\text { Rank }\end{array}$ \\
\hline $\begin{array}{l}\text { Banglades } \\
\mathrm{h}\end{array}$ & $\begin{array}{l}1 \\
3\end{array}$ & 5 & 11 & 13 & 8 & 10 & 13 & 13 & 7 & 10 & 12 & 13 & 8 & 11 & 11 & 13 \\
\hline Bhutan & $\begin{array}{l}1 \\
0\end{array}$ & - & 8 & 4 & 11 & 14 & 8 & 4 & 9 & 13 & 8 & 9 & 9 & 14 & 9 & 7 \\
\hline India & $\begin{array}{l}1 \\
1\end{array}$ & 11 & 10 & 9 & 12 & 11 & 10 & 9 & 11 & 8 & 10 & 8 & 11 & 10 & 8 & 8 \\
\hline Indonesia & 7 & 8 & 4 & 8 & 7 & 6 & 2 & 7 & 10 & 6 & 5 & 6 & 7 & 3 & 7 & 10 \\
\hline Malaysia & 3 & 1 & 5 & 2 & 5 & 1 & 4 & 2 & 5 & 3 & 4 & 2 & 4 & 4 & 4 & 2 \\
\hline Maldives & 5 & 10 & 6 & 5 & 2 & 7 & 5 & 5 & 2 & 9 & 6 & 5 & 2 & 8 & 10 & 4 \\
\hline Myanmar & $\begin{array}{l}1 \\
2\end{array}$ & 12 & 13 & 12 & 14 & 12 & 11 & 12 & 14 & 12 & 13 & 12 & 13 & 13 & 13 & 11 \\
\hline Nepal & 9 & 13 & 14 & 14 & 9 & 13 & 12 & 14 & 8 & 14 & 9 & 14 & 14 & 9 & 12 & 14 \\
\hline Pakistan & $\begin{array}{l}1 \\
4\end{array}$ & 7 & 12 & 10 & 13 & 9 & 14 & 11 & 13 & 11 & 14 & 11 & 12 & 12 & 14 & 12 \\
\hline $\begin{array}{l}\text { Philippine } \\
\text { s }\end{array}$ & 6 & 3 & 1 & 7 & 10 & 2 & 7 & 8 & 12 & 4 & 11 & 7 & 10 & 5 & 5 & 6 \\
\hline Singapore & 1 & 2 & 2 & 1 & 1 & 3 & 1 & 1 & 2 & 1 & 1 & 1 & 1 & 1 & 1 & 1 \\
\hline Srilanka & 4 & 4 & 7 & 6 & 4 & 4 & 3 & 6 & 4 & 2 & 2 & 4 & 3 & 2 & 3 & 5 \\
\hline Thailand & 8 & 6 & 3 & 3 & 6 & 5 & 6 & 3 & 6 & 7 & 3 & 3 & 6 & 7 & 2 & 3 \\
\hline Vietnam & 2 & 9 & 9 & 11 & 3 & 8 & 9 & 10 & 3 & 5 & 7 & 10 & 5 & 6 & 6 & 9 \\
\hline
\end{tabular}

\section{Dr. Nasheman Bandookwala}

Assistant Professor

\section{BA (Rural Economics), M. D. Gramsewa Sankul, Gujarat Vidyapith, Randheja, Gandhinagar}

March, 2021. VOL.13. ISSUE NO. 1 https://hrdc.gujaratuniversity.ac.in/Publication 
Towards Excellence: An Indexed, Refereed \& Peer Reviewed Journal of Higher Education / Dr.

Nasheman Bandookwala \& Dr. Hitesh Jagani/ Page 438-452

nasheman@gujaratvidyapith.org

$\boldsymbol{d}$

Dr. Hitesh N. Jagani

Assistant Professor

BRS (Rural Planning and Development), M. D. Gramsewa Sankul, Gujarat

Vidyapith, Randheja, Gandhinagar

hitesh.jagani@gujaratvidyapith.org 